This is the version of the article accepted for publication in International Business Review published by Elsevier, available at: http://dx.doi.org/10.1016/j.ibusrev.2016.11.003

Accepted version made available under the CC-BY-NC-ND 4.0 License from: http://eprints.soas.ac.uk/23283/

\title{
Antecedents and Consequences of Liking in Retail Service Relationships in China and
}

Greece

Ibrahim Abosag*; Thomas L. Baker; Kristina Lindsey Hall; Aliki-Dimitra Voulgari; Xiaoyuan

Zheng

* Ibrahim Abosag

SOAS University of London, Department of Financial and Management Studies

Thornhaugh Street, Russell Square, London WC1H OXG

Tel: 02078984223

e-mail: ia9@soas.ac.uk

Accepted in:

International Business Review 


\title{
Antecedents and Consequences of Liking in Retail Service Relationships in China and
}

\section{Greece}

\begin{abstract}
The marketing literature has provided a limited examination of the concept of liking, and even this has mainly occurred within business-to-business or advertising contexts. In this paper, the authors propose a model of the intervening role of liking in the customer-service provider relationship in two countries, China and Greece. The antecedents of liking include three key service constructs, namely customer education, customer participation, and service quality. The outputs of liking are proposed to be affective trust and affective commitment, which in turn influence (behavioral) loyalty. The research model is tested using samples from China $(\mathrm{N}=277)$ and from Greece $(\mathrm{N}=306)$. The model is largely supported in both samples. Therefore, the authors suggest that liking in financial services has an important role in the customer-service provider relationship. Implications for international businesses are discussed.
\end{abstract}

Keywords: International Marketing, Service Marketing, Liking, Loyalty, Financial Services, China, Greece. 


\subsection{Introduction}

While it is difficult to identify a single point where marketers turned their attention from a transactional perspective to one that is focused more on building and managing relationships between various constituencies including other business partners and consumers, certainly the influential papers by Berry (1983) and Dwyer, Schurr, and Oh (1987) provides a touchstone to this change in thinking. Since that time the idea of customer relationship management (CRM) has been a central tenet of marketing thought and encompasses a variety of relationships, including those between businesses and customers, businesses and businesses or, more recently and due to the use of social media, between customers themselves. Regardless, it has become imperative that firms manage these relationships and nowhere is that perhaps more important than in a services context. In fact, Bitner, Booms, and Tetreault (1990) used the term "moment of truth” to describe the importance of the interaction between the customer and the service employee as it relates to the ability of the firm to successfully manage that relationship and provide satisfactory service to the customer.

Given the importance of CRM, service marketers should avail themselves to any concepts that might provide insights into how this can be effectively accomplished. One such concept is that of 'liking.' While having been discussed to some extent in other areas such as business to business (B2B; Nicholson, Compeau, \& Sethi, 2001; Hawke \& Heffernan, 2006; Abosag \& Naudé, 2014; Dowell, Morrison, \& Heffernan, 2015), management (Nguyen, Melewar, \& Chen 2013) and advertising/branding (Keller, 1993; Ye \& van Raaij, 2004), there has been limited mention of liking within the services literature, especially in different countries. This is surprising given that liking has been said to be a cooperative trait (Stone, 2007) which is something that, given the recent importance placed on co-creation of value in service exchanges 
(c.f., Vargo \& Lusch, 2004), would appear to hold some promise as a way for service marketers to better engage in the management of relationships with customers in different cultures.

The purpose of this paper is to examine the concept of customer liking in a retail services context in different cultures. Specifically, the paper will examine customer liking in retail financial services in two different countries by developing and empirically testing a model of the antecedents and consequences of liking in service relationships. Since liking has a persuasive effect, as it can directly influence feelings and emotions (Biel and Bridgewater, 1990), China and Greece were selected based on the fact that customers from collectivist cultures involve more emotion and feelings in relationships (Jayakody and Sanjeewani, 2006). Essentially, this study makes the argument that countries that share similar cultural values develop similar psychological approach to relationships even between countries that have different banking systems and customer relationship management procedures. China scores low on Hofstede and colleagues' $(1997,2001)$ dimension of individualism at 20, which makes China the highest collectivist culture in Asia. Similarly, Greece at 35, also scores low in individualism making it the second highest collectivist culture in Europe. The antecedents of liking within the banking industries are identified as customer education, customer participation, and service quality. The consequences of liking include affective trust, affective commitment, and loyalty. We start by discussing the theoretical foundation of the model and the hypotheses. We then present the methodology used and review the results from the analysis utilizing samples from China and Greece. Finally, we discuss the findings, managerial and theoretical implications, and areas for future research. 
This is the version of the article accepted for publication in International Business Review published by Elsevier, available at: http://dx.doi.org/10.1016/j.ibusrev.2016.11.003

Accepted version made available under the CC-BY-NC-ND 4.0 License from: http://eprints.soas.ac.uk/23283/

\subsection{Conceptual Background}

Early studies within employee-organization relationship on liking tended to study liking and satisfaction (e.g. Locke, 1964). Both constructs, liking and satisfaction, have never been combined as one construct. In general, liking is an attitude whereas satisfaction is a global assessment of the state of relationships. Most studies on liking did not test for any association between satisfaction and liking and in fact these studies did not include satisfaction (e.g. Nicholson et al., 2001; Hawke \& Heffernan, 2006; Abosag and Naudé, 2014). Few studies tested relationship between liking and satisfaction (e,g, Locke, 1964; Hall et al., 2002). Within services literature liking is found that liking help maintain a state of satisfaction among client much longer than satisfaction without liking (Hall et al., 2002). Clearly within services liking is a major construct and according to Hall et al. (2002, p. 75) "liking can be studied in its own right as psychologically characteristic of the relationship”.

As mentioned previously, within a business context the concept of liking has most often occurred in the B2B (e.g., Hawke \& Heffernan, 2006; Nicholson et al., 2001) or advertising literatures (e.g. Walker \& Dubitsky, 1994). Both of these fields have for the most part drawn their conceptualizations from work in social psychology that focuses on interpersonal liking (Altman \& Taylor, 1973; Hendrick \& Hendrick, 1983; Rotter, 1980; Zajonc, 1980). However, even though liking is based on the interpersonal relationship literature, it has largely been overlooked by consumer relationship researchers, including those involved in service research where it would appear the concept of liking could provide relevant insights into managing service provider/customer relationships. Importantly, the concept of liking has also not been tested in different cultures, and nearly all previous research on liking focuses on individualistic cultures. Thus, the idea that there may be different evaluations of key service outcomes (e.g., 
This is the version of the article accepted for publication in International Business Review published by Elsevier, available at: http://dx.doi.org/10.1016/j.ibusrev.2016.11.003

Accepted version made available under the CC-BY-NC-ND 4.0 License from: http://eprints.soas.ac.uk/23283/

trust and commitment) resulting from liking among collectivist cultures warrants a deeper investigation.

The branding literature has shown that customers choose to enter relationships with brands just as they do with other people (e.g. Fournier, 1998; Hayes et al., 2006; Zayer and Neier, 2011). Theories of consumer behavior have also revealed that people form self-brand connections (Escalas and Bettman, 2005). Brands are found to help customers articulate their identities (Aaker, 1996) and form relationships with them (Mukherjee and Balmer, 2007, Mukherjee \& He, 2008; Mangold and Faulds, 2009) through the development of sufficient levels of liking (Stone 2007) as they offer two main resources. First, brands offer the actual benefits that are realized from using and experiencing the product or service (Reimann and Aron, 2009). Second, brands suggest something unique about the customer to others within their social circle (Escalas and Bettman, 2009). Therefore, brands/institutions can offer social capital and resources in different forms including status created by brand possession and recognition by others, as well as an opportunity for self-expression via brands.

In the social-psychology literature, liking is generally defined as an attitude towards a person based on an emotional bond which is focused at the personal relationship level and emphasizes cognitive, affective, and behavioral beliefs (Hendrick \& Hendrick, 1983; Rotter, 1980). In the B2B literature, liking at the interpersonal level is defined as "the global affective attachment” between business partners (Nicholson et al., 2001, p. 5). Similarly, in a banking/financial services context liking is defined as “an ability to 'get on' or be comfortable with the other party in a bank lender - business customer relationship; based on a positive attitude each person has for the other and the recognition of the existence of an affirmative 
This is the version of the article accepted for publication in International Business Review published by Elsevier, available at: http://dx.doi.org/10.1016/j.ibusrev.2016.11.003

Accepted version made available under the CC-BY-NC-ND 4.0 License from: http://eprints.soas.ac.uk/23283/

emotional connection” (Hawke \& Heffernan, 2006, p. 145). As can be noted, there are very few differences in these definitions even though they come from quite different areas.

Liking is considered to be a "reactive" construct since it is typically a response toward liked behaviors or meanings provoked by another individual or entity (Davis, 1985). Cialdani (2004) argues, though, that liking should be distinguished from other reactive behaviors due to its ability to create positive long-term interactive responses. Furthermore, Stone (2007) considers liking to be a cooperative trait rather than a character trait, thus further highlighting the ability of liking to facilitate relationship development. This is not to say that liking is easily established. Rather, Zajonc (1980) points out that liking "occurs only after considerable cognitive operations have been accomplished,” implying that it may be difficult to engender liking within a relationship (p. 151).

Regardless, evidence indicates it would be worth the effort to engage in activities that would lead to liking, particularly given the need for service providers to create stronger relationships with their customers. This is attributable to research which has shown that liking can act to enhance relationships. Specifically, research indicates that liking leads to a propensity for individuals to remain in relationships (Altman and Taylor, 1973; Swan, Trawick, \& Silva, 1985), improves the rating of a relationship (Carnevale, Pruitt, \& Carrington, 1982; Khare, Labrecque \& Asare, 2011), increases relationship attraction (Byrne, 1971; Caballero \& Resnik, 1986), predicts the perceived quality of a relationship (Liden, Wayne, \& Stilwell, 1993), and perhaps most importantly given the current context, enhances the evaluation of a service experience (Jayanti \& Whipple, 2008). In addition to enhancing the nature of the relationship from the perspective of the individual in which liking is created, there is some evidence that liking can have a "reciprocal" positive impact on the party which is liked. Sternberg (1987) 
This is the version of the article accepted for publication in International Business Review published by Elsevier, available at: http://dx.doi.org/10.1016/j.ibusrev.2016.11.003

Accepted version made available under the CC-BY-NC-ND 4.0 License from: http://eprints.soas.ac.uk/23283/

reported that those who acted in a way that led to liking would engage in those behaviors in the future in order to assure the continuation of being liked. In a services context, this would imply that service employees who recognize they are liked by customers would tend to engage in the behaviors they believe most likely led to their being liked.

\subsection{Modeling the Antecedents and Consequences of Liking}

Much of the early discussion grounds liking in the interpersonal relationship social psychology literature. However, liking within services is not only based on pure interpersonal relationship between customers and financial institutions. Liking within retail services environment involves two levels, each level is as important depending on the degree of human involvement in the service interaction. The first is interpersonal-based liking usually discussed with B2B liking (e.g. Nicholson et al., 2001; Hawke \& Heffernan, 2006). The second level is environment based liking which include brand, physical surroundings, and atmospheric experience. Ennew and Binks (1999) found that, as it relates to a customer-bank relationship, "the institutional atmosphere of the relationship is of considerable importance" to customer interaction and participation in service design, delivery, and quality (p.130). Thus, liking in a services environment should not only be defined at the interpersonal level, but should include the institutional atmosphere surrounding the relationship, which has a significant influence on customer liking. Customer liking of bank services comes from a nice/positive experience (Jayanti \& Whipple, 2008), a positive atmosphere (Bailey \& Areni, 2006; Ennew \& Binks, 1999; Gremler \& Gwinner, 2008), and consistency compared to other banks (Schneider \& Bowen, 1985). Therefore, beside the emotional attitude of liking, customer liking in financial services is defined as a positive attitude 
This is the version of the article accepted for publication in International Business Review published by Elsevier, available at: http://dx.doi.org/10.1016/j.ibusrev.2016.11.003

Accepted version made available under the CC-BY-NC-ND 4.0 License from: http://eprints.soas.ac.uk/23283/

a customer has toward a bank that has a nice and pleasant experience and a positive institutional atmosphere, and which has proved to be more consistent compared to other banks.

Conceptualization of models in services has largely overlooked the impact of liking on the customer-service provider relationship. It has long been argued that, "the inclusion of liking may offer greater explanatory power beyond models that rely solely on the more cognitive aspects of the relationship” (Nicholson et al., 2001, p. 4). Liking was found to carries more predictive weight above and beyond customer’s overall satisfaction (Hall et al., 2002). Such important influence has recently been recognized, especially with the recognition of the important role of customer in creation and delivery of value within customer-retailer relationship within services (Vargo and Lusch, 2004). Hall et al. (2002) found liking has some form of reciprocity in services. As customers are co-producers of services (Vargo and Lusch, 2004), liking in services is contingent on inputs from each party of the relationship. Enabling customers to be co-producers of value in complex services requires educating them (Kelley, Donnelly, \& Skinner, 1990), which in turn increases their perceived control over the service delivery process (Bateson, 1985) boosting their liking. Through this process the relationship is enhanced and strengthened (Bettis-Outland, Guo, \& Ng, 2012; Suwelack, Hogreve, \& Hoyer, 2011) thus increasing customer overall loyalty.

The next section is a conceptualization of the antecedents of liking, which include customer participation, customer education, and service quality. This is followed by a closer examination of the consequences of liking, which include affective trust, affective commitment, and loyalty. We chose to include only affective elements of trust and commitment in part due to the cultural context (Chinese and Greek) of the study (e.g. Hofstede et al., 1991) but also because studies on trust and commitment in collectivist cultures show that affective elements have 
significantly higher impact than cognitive elements (e.g. Williams, Han, \& Qualls, 1998; Cater and Zabkar, 2009). Given that both are collectivist cultures, it is likely that affective aspects of trust and commitment as well as loyalty (Rodríguez \& Wilson, 2002; Baker, Meyer, \& Chebat, 2013) are more important relative to long-term interactions. Thus, this study only considered these aspects. The hypotheses presented below are summarized in Figure 1.

\section{FIGURE 1}

\section{The Conceptual Model of Relationship Liking}

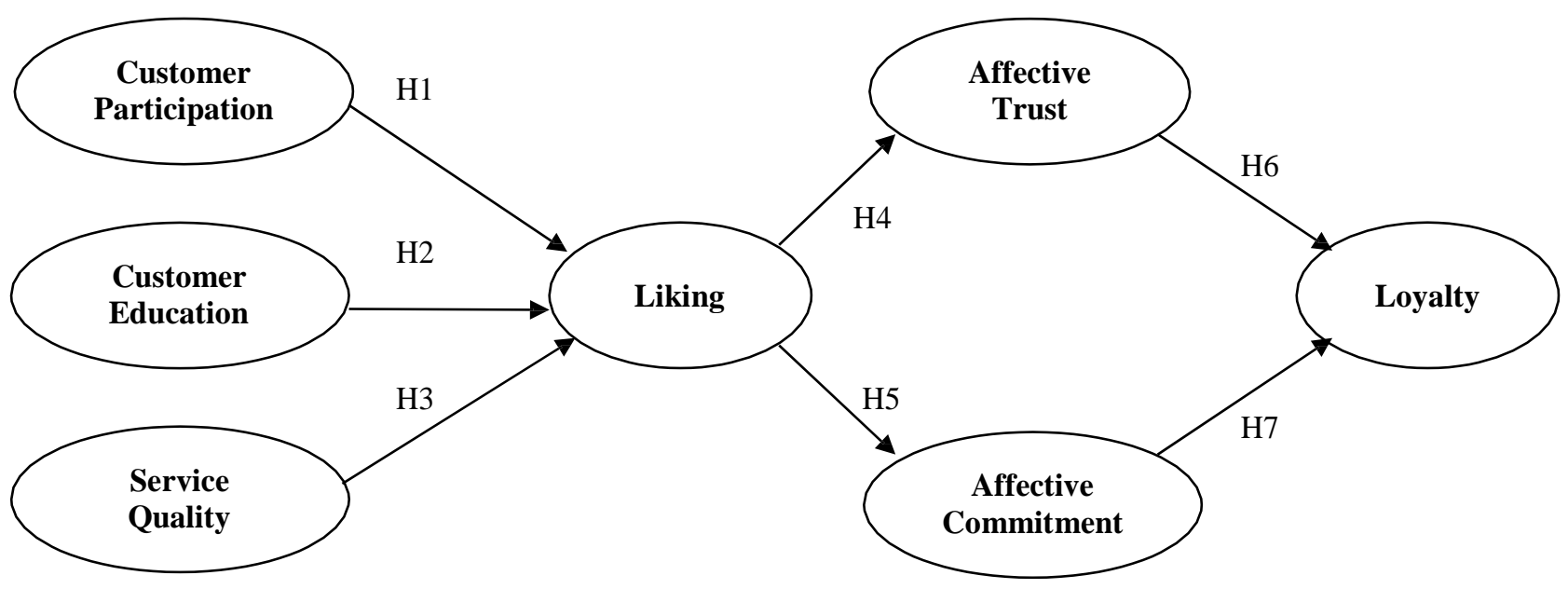

\subsection{Antecedents of Liking}

\subsubsection{Customer Participation}

Customer participation, co-development, co-production, customer involvement, customer influence, and customer contact are common concepts used in the literature to refer to the amount or degree of customer participation in a service system (Edvardsson, Gustafsson, Kristensson, \& Witell, 2010). According to involvement theory (Clarke \& Belk, 1978) and service dominant logic (Vargo \& Lusch, 2004), customers have progressed from being a 
“passive audience” to “active players” as it relates to the provision of service. Dabholkar (1990) defined customer participation as "the degree to which the customer is involved in producing and delivering the service” (p. 484). Rodie and Kleine (2000) defined it as "the actions and resources supplied by customers for service production and/or delivery” (p.100). While these definitions reflect a similar meaning of customer participation, we conceptualize customer participation as a customer's willingness to make constructive suggestions and recommendations regarding how service delivery can be improved (Bettencourt, 1997). Research interests in customer participation started three decades ago (Eiglier \& Langeard, 1977; Lovelock \& Young, 1979). By the 1990s, a great deal of intensive interest focused on customer participation (Bendapudi \& Leone, 2003; Bitner, Faranda, Hubbert, \& Zeithaml, 1997; Ennew \& Binks, 1999; Fang 2008; Folse, Niedrich \& Grau, 2010; Kelley et al., 1990; Lengnick-Hall, 1996).

Customer participation is often required for some services to be produced. For example, higher levels of involvement/participation tend to exist in services that are considered complex such as with consulting or banking (Ennew \& Binks, 1999). In such cases the quality of a service often highly depends on the part played by the customer (Kelley et al., 1990). In fact, for many complex services the customer can be viewed as a partial employee and is an essential part of the service delivery process (Lovelock \& Young, 1979). Furthermore, according to Lee, Kim, and Yoo (2009), by increasing customer participation, service providers can increase service satisfaction and mitigate the risks brought about due to a lack of customer knowledge and skills regarding the service delivery process, which is more likely to occur for complex services. From a psychological perspective, customers tend to give additional value to those services for which they have been a part of the delivery process (Norton, Frost, \& Ariely, 2007). Additionally, customer participation has been shown to provide numerous benefits to service providers. For 
This is the version of the article accepted for publication in International Business Review published by Elsevier, available at: http://dx.doi.org/10.1016/j.ibusrev.2016.11.003

Accepted version made available under the CC-BY-NC-ND 4.0 License from: http://eprints.soas.ac.uk/23283/

example, participation provides more tangible benefits such as allowing service providers to better customize and deliver a more satisfying product (Bettencourt, 1997) which can further lead to higher levels of service innovation (Fang, 2008; Kristensson, Gustafsson, \& Archer, 2004). Participation also has more relational impacts such as aiding in reductions in customer switching behavior (Eisingerich \& Bell, 2006), helping to increase mutual understanding (Mohr \& Bitner 1991), allowing for more favorable assessments of the organization (Auh, Bell, McLeod, \& Shih, 2007), increasing customers' positive emotions toward the service provision (Kelley \& Hoffman, 1997; Price, Arnould, \& Deibler, 1995), and, perhaps most importantly in the current context, increasing relationship enjoyment, attractiveness and liking (Bitner et al., 1990; Dobscha \& Foxman, 2012; Jayanti \& Whipple, 2008) which can improve firm performance (Verhoef et al., 2010).

H1: Customer participation positively influences customer-service provider relationship liking.

\subsubsection{Customer Education}

Customer education is defined by Burton (2002) as the extent to which service firms provide customers with the skills and knowledge necessary to effectively utilize information and participate in the co-production of value process. Education has also been found to be necessary for the mutual success of the relationship by service providers and customers (Burton, 2002; Lengnick-Hall, 1996). This is particularly true for services that tend to be complex and difficult to understand (Moutinho \& Smith, 2000). Sharing information and knowledge with customers in professional services is essential to its success (Sharma \& Patterson, 1999). Some services go so far as to provide one-to-one education for its customer, which in part, helps reduce adoption barriers (Karjaluoto, Laukkanen, \& Kiviniemi, 2010). 
Customer education is effective in setting realistic customer expectations (Bitner et al., 1997), reducing information asymmetries between the firm and its customers (Nayyar, 1990), and improving customer experiences (Verhoef et al., 2009), which lead to a greater level of customer retention (Xue \& Harker, 2002). Customer education also helps customers reduce uncertainty (Bitner et al., 1997) and improve their perception about the quality of the service proposition Further, Bell and Eisingerich (2007) and Burton, Howlett, and Tangari (2009) argued that consumer education has been used not only to differentiate from competitors, but also to add value to service offerings.

Customer education may arguably result in two long-term effects. The first is that the more service firms educate their customers, the more vulnerable they are to losing them (Levitt, 1980). Bell and Eisingerich (2007) called this "the paradox of customer education,” where customers who are becoming 'experts' about a service process may either behave opportunistically or leave the relationship. The opposite view argues that expert customers are more likely to develop more likability toward the relationship with the service provider (Smith \& Cooper-Martin, 1997). Thus, a longer-term relationship with expert customers can be better managed and maintained (Dellande, Gilly, \& Graham, 2004). According to Burton (2002), customer education can lead to more advantages and at the same time can cause vulnerability. While this unresolved argument is open for debate, close examination of previous studies on customer education shows that these studies have mainly focused on cognitive effects toward the service and its impact on customer loyalty (e.g., Burton, 2002; McNeal, 1978; Xue \& Harker, 2002). Almost all of these studies were generated from individualistic cultures focusing more on the cognitive effects of customer education. Less attention has been paid to customer education within collectivist cultures where more affective effects of customer education may be more important in the customer-service 
provider relationship. Subsequently, we argue that customer education increases customer liking of the relationship with the service provider.

H2: Customer education positively increases customer-service provider relationship liking.

\subsubsection{Service Quality}

Service quality has been by far the most researched aspect of services marketing. In part, this is because the quality of the service can be the sole differentiator between service providers (Parasuraman, Zeithaml, \& Berry, 1985). Service quality is defined as the “consumer’s judgment about the superiority or excellence of a product” or service (Zeithaml, 1988, p.5). The term 'service quality' refers to a long-term attitude by customers toward the service provider (e.g. Parasuraman, Zeithaml, \& Berry, 1994). This attitude is positively related to customers' likelihood of remaining in the relationship (Antón, Camarero, \& Carrero, 2007). While compelling evidence exists that service quality is a strong predictor of variables such as purchase intensions, loyalty, trust, and commitment, among others (e.g. Bolton \& Drew, 1991; Parasuraman et al., 1994; Sivakumar, Li, \& Dong, 2014; Taylor \& Baker, 1994), some recent studies show service quality to not have a direct relationship with some of these variables (e.g. Kandampully \& Hu, 2007). Other studies show that service quality only influences some of these variables through perceived value (e.g. Lai, Griffin, \& Babin, 2009) or customer satisfaction (e.g. Dabholkar, Shepherd, \& Thorpe, 2000; Yim, Chan, \& Hung, 2007).

We follow the approach advocated in the final group of studies discussed above, that being the idea that the impact of service quality on constructs such as trust, commitment, and loyalty may not be direct, but rather service quality impacts those constructs via the intervention of customer liking. Since, in professional services, service quality is often produced through two 
individuals (service interaction), there is a substantial impact on customers' favorable perceptions (Bowen \& Schneider, 1988). Positive perceptions of service quality affect consumers' feeling and liking (Hurley \& Estelami, 1998); thus, a positive perception of service quality increases the likelihood that consumers develop more liking not only toward the services provided but also toward their relationship with service providers. The stronger the service quality, the more likely are consumers to reduce uncertainty and increase their liking for the relationship (Cox \& Cox, 2002). Moreover, and since service quality is an evaluative construct that drives consumer liking and indirectly shapes future relational behavior, consumers' evaluation of service quality varies across cultures (Winsted, 1997; Mattila, 1999) which in turn affects their future type of relationship (Furrer, Liu \& Sudharshan, 2000). These are particularly true for collectivist cultures, which are found to rely more on intangible and emotional cues of services quality (Mattila, 1999; Abosag \& Naudé, 2014; Spence, Puccinelli, Grewal, \& Roggeveen, 2014) thus increasing customer liking of their relationship with a service provider.

H3: Service quality positively influences customer liking of their relationships with service providers.

\subsection{Consequences of Liking}

\subsubsection{Affective Trust}

Numerous studies have viewed trust as an expression of confidence between the partners in a relationship (e.g. Dwyer et al., 1987; Garbarino \& Johnson, 1999). In industrial marketing, Swan et al. (1985) and Nicholson et al. (2001) found that customers who perceive their partners to be likable also tend to have more trust in them. A positive relationship was found to exist between liking and the level of trust (Doney \& Cannon, 1997; Dowell et al., 2015; Rotter, 1980) where 
liking boosts confidence of customers and enables them to predict their future relationship with their partner (Swan et al., 1985).

In services, Bove and Johnson (2001) argued that liking is an antecedent of trust and commitment. Similarly, Bendapudi and Berry (1997) and Abosag and Lee (2013) indicated that liking and social bonding increase trust and assist in maintaining commitment to relationships. More recent studies (Johnson \& Grayson, 2005; Schaubroeck, Lam, \& Peng, 2011) differentiate between two distinct dimensions of trust. Namely, cognitive trust is defined as the customer's willingness or confidence to rely on a service provider’s competence (Moorman, Zaltman, \& Deshpande, 1992), and affective trust is the customer's confidence based on feelings generated by the overall liking of a partner (Rempel, Holmes, \& Zanna, 1985). We focus on affective trust as it "is decidedly more confined to personal experiences with the focal partner than cognitive trust” (Johnson \& Grayson, 2005, p. 501). Within the context of this study, we define affective trust as the confidence a customer places in a service provider based on feelings generated by the level of caring and liking the service firm demonstrates.

In social psychology studies, liking is considered an important driver in the building of affective trust (Lewis \& Weigert, 1985; Zaccaro \& McCoy, 1988). Further, in industrial marketing, the core of affective trust is a reliance on a partner's liking and emotions (Johnson \& Grayson, 2005) which drives the entire relationship (Bettis-Outland et al., 2012). Nicholson et al. (2001) argued that, in the presence of liking in the relationship, cognitive aspects of trust "recede into the background and cease to have any direct relationship with trust” (p. 3). Within professional services, affective trust is more relevant as service interaction tends to generate close personal experiences with service encounters (Dwyer, 2007) forming personal attachment and liking, which in turn enhances the economic bond. Some researchers view affective-based 
This is the version of the article accepted for publication in International Business Review published by Elsevier, available at: http://dx.doi.org/10.1016/j.ibusrev.2016.11.003

Accepted version made available under the CC-BY-NC-ND 4.0 License from: http://eprints.soas.ac.uk/23283/

trust as higher level trust (Geyskens, Steenkamp, Scheer, \& Kumar, 1996), which has been found to be more influential in collectivist cultures than in individualistic cultures (Rodríguez \& Wilson, 2002).

H4: Relationship liking positively increases affective trust in customer-service provider relationships.

\subsubsection{Affective Commitment}

Commitment has been identified as an essential element of successful, long-term relationship development. O’Malley and Tynan (1997) argue that the existence of one committed party in a relationship does not automatically suggest that all parties in the relationship are committed. In a B2B context, Hawke and Heffernan (2006) found that "an increase in liking led to an increase in commitment” (p.153). Thus, customer liking is a prerequisite for affective commitment. This is because it is based on a sense of liking and emotional attachment to the partnership (Wang, 2014), increases customers' sense of belonging and gives them a "psychological hug" (Sanders, 2006). A committed relationship partner desires to continue the relationship because he/she likes and enjoys the relationship (Jaros, Jermier, Koehler, \& Sincich, 1993).

In the branding literature, the relationship between customer liking of a brand increases customer affective commitment (Amine, 1998), as it allows for the formation of relationships (Mukherjee and Balmer 2007) and for self-expression (Aaker, 1996). Similarly, Pimentel and Reynolds (2004) found that fans who have a 'strong liking' develop an affective commitment to the relationship with a club. Furthermore, Fullerton (2003) argued that affective commitment is driven by liking. Other studies indicate that liking of a partner helps in the development of affective commitment (Abosag \& Lee, 2013; Wetzels, De Ruyter, \& Van Birgelen, 1998) and that an affectively committed partner continues the relationship because of a high level of liking 
This is the version of the article accepted for publication in International Business Review published by Elsevier, available at: http://dx.doi.org/10.1016/j.ibusrev.2016.11.003

Accepted version made available under the CC-BY-NC-ND 4.0 License from: http://eprints.soas.ac.uk/23283/

(Jaros et al., 1993). This sense of liking that helps generate affective commitment has been described as "a sense of belonging or being 'part of the family' " (Auh et al., 2007, p. 362). We define affective commitment as the emotional desire to attach to, identify with, care about, and be involved with a service organization.

H5: Relationship liking positively increases affective commitment in customer-service provider relationships.

\subsubsection{Impacts on Loyalty}

Customer loyalty is defined as a consumer's intent to stay with an organization and their willingness to increase the depth (i.e. through increased transaction volume) and breadth (i.e. through increased scope of products purchased) of their relationship with the organization (Zeithaml, Berry, \& Parasuraman, 1996). Affect and emotion are key drivers of loyalty. Wong (2004) found that a customer's feelings are an important predictor of customer loyalty. Loyalty is dependent on the development of a number of interpersonal relationship constructs including affective trust and affective commitment (Fullerton, 2003; Keaveney, 1995). Similar to Dean (2007), we distinguish between these constructs by defining and measuring behavioral loyalty compared to the affective and emotional aspects of trust and commitment. Harris and Goode (2004) demonstrate the pivotal impact of trust on loyalty. Further, Schurr and Ozanne (1985) argued that trust has an important influence on dyadic interactions and leads to a stronger form of loyalty. Similarly, this study makes the point that, within professional services, affective trust is particularly impactful for customer perceptions of loyalty.

H6: Affective trust positively increases loyalty in customer-service provider relationships. 
The link between commitment and loyalty has long been established. Garbarino and Johnson (1999) and Gundlach, Achrol, and Mentzer (1995) found overall commitment to positively influence loyalty. Amine (1998) concluded that affective commitment tends to reduce the propensity for substitution and increase loyalty in the relationship. Strong affective commitment motivates consumers to make meaningful contributions to organizational outputs (Meyer \& Allen, 1991) and allows them to stay loyal in the relationship (Kim, Hibbard, \& Swain, 2011). Fullerton (2003) found, in the service context, that affective commitment has the strongest impact on customer loyalty compared with other types of commitment. Similarly, Evanschitzky, Iyer, Plassmann, Niessing, and Meffert (2006) found affective commitment “influences loyalty to a much higher degree” (p. 1212). Based on these findings, this study hypothesizes the following.

H7: Affective commitment positively improves loyalty in customer-service provider relationships.

\subsection{Methods}

\subsubsection{Overview of Research}

Data used to test the aforementioned hypotheses (as proposed in Figure 1) were collected utilizing two sampling techniques - data collection directly with the largest bank in each of our target countries, and a mall-intercept approach -, which are described below. Constructs were measured using 7-point, multi-item scales anchored by strongly disagree and strongly agree, with the exception of liking. For the liking construct, preliminary interviews were conducted to assess customer liking and relationship preferences, which were then used to develop and test a liking scale. LISREL 8.51 was used to conduct the analyses in this study. First, a confirmatory factor analysis was conducted and tests to assess the reliability and validity of the measures were performed. Then, tests were performed to determine if the proposed paths were significant for 
This is the version of the article accepted for publication in International Business Review published by Elsevier, available at: http://dx.doi.org/10.1016/j.ibusrev.2016.11.003

Accepted version made available under the CC-BY-NC-ND 4.0 License from: http://eprints.soas.ac.uk/23283/

each sample. Next, configural and metric invariance were tested in order to assure the items were loading similarly across the samples so that the extent to which the country moderates the proposed relationships could be tested.

\subsubsection{Sample}

A structured survey was used to collect the data from China and Greece in June 2008. The research model is tested using samples from China $(\mathrm{N}=277)$ and from Greece $(\mathrm{N}=306)$. Two sampling techniques were used in both countries. The first technique involved using the biggest bank in China (Bank of China) and in Greece (National Bank of Greece) to facilitate access to their customers. About 39\% of responses were obtained through the bank in China compare to 28.4\% in Greece. The second technique involved distributing the questionnaires in public places such as major shopping malls and train stations in Beijing and Athens. Respondents were asked not to take part in the study unless they have more than 1-year relationship with their favorite bank. The study only includes respondents over 18 years old. The sample from China contains 46.9\% male and 53.1\% female compare to 52\% male and $48 \%$ female from Greece. The gender show good equivalence level. Average age of the respondents from China is 26 years old compare to 35 years old in Greece. At the time of collecting the data, over 68\% of respondents from China have had more than one relationship with different banks compared to $79 \%$ of respondents from Greece. The remaining percentages (32\% in China and 21\% in Greece) did have previous relationships with other banks but not during the data collection.

\subsubsection{Measurement}

Constructs in the model were measured using seven point Likert-scales anchored by 1 (Strongly Disagree) and 7 (Strongly Agree) all of which were adopted and modified from existing studies, with the exception of liking. The scales for customer participation and 
customer education were adopted from Eisingerich and Bell (2006). The scale for service quality was adopted from Brady, Cronin, and Brand (2002). The scale measuring affective trust was adopted from Johnson and Grayson (2005). Affective commitment was measured using a scale developed by Fullerton (2003). Finally, loyalty was measured a scale developed by Zeithaml et al. (1996).

As to liking, which was developed for this study, prior to the data collection, the authors conducted 14 interviews asking participants to define their liking of their favourite brand in services that they consider having relationships with. The average age of participants was 29 years old with 8 male and 6 female. Given the nature of this study, participants were selected from China, Greece and the UK (this was done in part due to some of the researchers being based in the UK). The interviews were conducted in English. A pool of 22 items measuring liking were generated. These items were then piloted on 67 respondents. This data was submitted to an exploratory factor analysis (EFA) using principal components analysis and a varimax rotation. This resulted in a four-factor solution with 17 items loading on the first factor. As the five items that loaded on the other three factors and all had loadings below .50 all were deleted. Of the 17 remaining items, 3 had low loadings on the first factor and/or high cross-loadings and were removed from further analyses. This group of 14 items was further assessed via data collected from 36 respondents that was again submitted to an EFA as described above. This resulted in a 3-factor solution with 8 items loading strongly (>.50) on a single factor. Since the other 6 items showed a pattern of low loadings $(<.40)$ on the first factor and an inconsistent pattern of cross-loadings, they were dropped. An additional EFA of the remaining 8 items indicated two items had relatively low loadings, which was consistent with the other EFA analyses, thus they were dropped. The six remaining items all loaded strongly on a single factor, 
exhibited a suitable AVE (>.50) and showed consistent reliability across the three data collections. Eventually, the more rigorous CFA analysis conducted with all items measuring all constructs led to three additional items being removed. These items reflect the extent respondents feel nice about the bank more than other banks, the liking of the bank based on the consistence it maintains compares with other banks, and the liking of the good and positive atmosphere within the bank. The items used to measure each construct are presented in Table 1.

The scales were first written in English and then translated into Chinese and Greek. The back-translation method introduced by Brislin (1986) was used to ensure linguistic equivalence. In order to assess content validity of the measures, experts with good experience and in-depth understanding of both languages (English and Chinese/Greece) were asked to evaluate the adequacy of the developed measured alongside the constructs' definitions. Few amendments were made to the questionnaire. This includes light modifications for seven items in the Greek version and four items in the Chinese version. The changes were restricted to minor issues such as changes in verb tenses and the ordering of some words given differences in the languages. Once we felt comfortable with the quality of the translation, the questionnaire was then used in collecting the data from China and Greece.

In order to assure the items would be useful to test the hypotheses, we assessed validity via a confirmatory factor analysis using LISREL 8.51 (Jöreskog \& Sörbom, 2001). To ascertain the extent to which our model provided an appropriate fit to the data, we followed suggestions by Hu and Bentler (1999) to use CFI and IFI as incremental fit measures and SRMR as a measure of absolute fit in addition to the $\chi^{2}$ statistic. Based on these criteria, both samples provide a goodfit. For the Chinese sample the $\chi^{2}$ was significant $\left(\chi^{2}=272.94_{(168)}, \mathrm{p}=.000\right)$ but the other fit statistics indicated good fit. The CFI (.96) and IFI (.96) values were acceptable as was the SRMR 
This is the version of the article accepted for publication in International Business Review published by Elsevier, available at: http://dx.doi.org/10.1016/j.ibusrev.2016.11.003

Accepted version made available under the CC-BY-NC-ND 4.0 License from: http://eprints.soas.ac.uk/23283/

(.04). The Greek sample exhibited a very similar fit. Again, the $\chi^{2}$ was significant $\left(\chi^{2}=\right.$ 326.69(168), $\mathrm{p}=.000)$ but the CFI (.98) and IFI (.98), along with the SRMR (.03) were all above or below the level indicative of a good fit. In addition, with all parameter estimates were above .6 with the exception of one, which was .56, and all t-values for the item loadings were greater than 2.0, which provides some evidence of convergent validity (Segars, 1997). Furthermore, the composite reliability for all constructs were quite high (the lowest was .84) and the average variance extracted values were all above .5. Table 1 presents the completely standardized factor loadings along with the t-values, composite reliability, and average variance extracted. 
This is the version of the article accepted for publication in International Business Review published by Elsevier, available at: http://dx.doi.org/10.1016/j.ibusrev.2016.11.003

Accepted version made available under the CC-BY-NC-ND 4.0 License from: http://eprints.soas.ac.uk/23283/

Table 1 Parameter Estimates, Average Variance Extracted, and Composite Reliabilities

\begin{tabular}{|c|c|c|}
\hline Items & Chinese Sample & Greek Sample \\
\hline Customer Education & $\begin{array}{l}\mathrm{AVE}=.54 \\
\mathrm{CR}=.89\end{array}$ & $\begin{array}{l}\mathrm{AVE}=.59 \\
\mathrm{CR}=.90\end{array}$ \\
\hline $\begin{array}{l}\text { The bank keeps me very well informed about what is going on with my } \\
\text { accounts/investments. }\end{array}$ & $.62^{1}(*)^{2}$ & $.67^{1}(*)^{2}$ \\
\hline $\begin{array}{l}\text { The bank explains financial concepts and recommendations in a } \\
\text { meaningful way. }\end{array}$ & $.73(9.25)$ & $.89(12.00)$ \\
\hline The bank always offers as much information as I need. & $.83(9.93)$ & $.74(10.56)$ \\
\hline $\begin{array}{l}\text { The bank always explains the pros and cons of the investment } \\
\text { recommended to me. }\end{array}$ & $.75(9.43)$ & $.75(10.70)$ \\
\hline Customer Participation & $\begin{array}{l}\mathrm{AVE}=.51 \\
\mathrm{CR}=.84\end{array}$ & $\begin{array}{l}\mathrm{AVE}=.61 \\
\mathrm{CR}=.89\end{array}$ \\
\hline $\begin{array}{l}\text { When I experience a problem at the bank, I let someone know so they } \\
\text { can improve service quality. }\end{array}$ & $.73(*)$ & $.66(*)$ \\
\hline I let this bank know of ways that they can better serve my needs. & $.75(9.12)$ & $.87(10.63)$ \\
\hline $\begin{array}{l}\text { If I have a useful idea on how to improve service, I give it to someone at } \\
\text { the bank. }\end{array}$ & $.67(8.75)$ & $.80(10.48)$ \\
\hline Service Quality & $\begin{array}{l}\mathrm{AVE}=.63 \\
\mathrm{CR}=.90\end{array}$ & $\begin{array}{l}\mathrm{AVE}=.63 \\
\mathrm{CR}=.89\end{array}$ \\
\hline Generally, the employees provide service reliably and consistently. & $.82(*)$ & $.90(*)$ \\
\hline $\begin{array}{l}\text { Generally, the employees are willing and able to provide service in a } \\
\text { timely manner. }\end{array}$ & $.85(15.04)$ & $.88(18.00)$ \\
\hline Generally, the physical facilities and employees are neat and clean. & $.70(12.02)$ & $.56(9.78)$ \\
\hline Liking & $\begin{array}{l}\mathrm{AVE}=.69 \\
\mathrm{CR}=.89\end{array}$ & $\begin{array}{l}\mathrm{AVE}=.79 \\
\mathrm{CR}=.95\end{array}$ \\
\hline I like this bank more than other banks because it has been nice. & $.73(*)$ & $.92(*)$ \\
\hline I like this bank more than other banks because it has been consistent. & $.80(11.98)$ & $.84(19.49)$ \\
\hline I like this bank more than other banks because it has a good atmosphere. & $.85(12.10)$ & $.90(22.44)$ \\
\hline Affective Trust & $\begin{array}{l}\mathrm{AVE}=.60 \\
\mathrm{CR}=.88\end{array}$ & $\begin{array}{l}\mathrm{AVE}=.79 \\
\mathrm{CR}=.95\end{array}$ \\
\hline $\begin{array}{l}\text { If I share my problems with the bank, I feel the bank would respond } \\
\text { caringly. }\end{array}$ & $.75(*)$ & $.90(*)$ \\
\hline The bank displays a warm and caring attitude toward me. & $.85(13.31)$ & $.95(24.44)$ \\
\hline $\begin{array}{l}\text { I can talk freely with my financial advisor about my problems at work } \\
\text { and know that he or she will want to listen. }\end{array}$ & $.71(11.13)$ & $.82(18.27)$ \\
\hline Affective Commitment & $\begin{array}{l}\mathrm{AVE}=.63 \\
\mathrm{CR}=.86\end{array}$ & $\begin{array}{l}\mathrm{AVE}=.80 \\
\mathrm{CR}=.94\end{array}$ \\
\hline I feel some sense of identification with this bank. & $.70(*)$ & $.85(*)$ \\
\hline I take pleasure in being a customer of this bank. & $.88(11.87)$ & $.94(18.27)$ \\
\hline Loyalty & $\begin{array}{l}\text { AVE }=.67 \\
\text { CR }=.92\end{array}$ & $\begin{array}{l}\mathrm{AVE}=.89 \\
\mathrm{CR}=.98\end{array}$ \\
\hline I say positive things about this bank to other people. & $.79(*)$ & $.941(*)$ \\
\hline I recommend this bank to someone who seeks my advice. & $.87(14.87)$ & $.97(33.82)$ \\
\hline I encourage friends and relatives to use this bank. & $.81(13.77$ & $.92(28.71)$ \\
\hline
\end{tabular}


This is the version of the article accepted for publication in International Business Review published by Elsevier, available at: http://dx.doi.org/10.1016/j.ibusrev.2016.11.003

Accepted version made available under the CC-BY-NC-ND 4.0 License from: http://eprints.soas.ac.uk/23283/

Additional tests to further assess validity and reliability of the constructs were also conducted. Discriminant validity was assessed using the method proposed by Fornell and Larcker (1981), which consists of comparing the shared variance between two constructs with the average variance extracted for each construct. Discriminant validity is evident if the average variance extracted is greater than the shared variance. There were no discriminant validity issues with the Greek data. Within the Chinese sample, discriminant validity was not an issue with the exception of loyalty and affective commitment. In this case the shared variance between loyalty and affective commitment was .68 while the AVEs for those two constructs were .67 and .63, respectively. As these values are very close to being indicative of discriminant validity, we chose to include the constructs in our analyses. Reliability was assessed via construct reliability. As can be seen in Table 1 those values are all quite high, falling between .84 and .98 thus indicating a high degree of reliability. Finally, we calculated variance inflation factors (VIF) for each construct to ensure multicollinearity was not an issue. As can be seen in Table 3 all VIF's are below the common threshold of 10 indicating multicollinearity does not appear to an issue. Means, standard deviations, correlations among the constructs, and VIFs for both samples are presented in Table 3. We will note that construct means indicate most measures were in the mid-range of the possible scale values (i.e., 1 to 7) and that standard deviations are consistent across both samples for all constructs. 
This is the version of the article accepted for publication in International Business Review published by Elsevier, available at: http://dx.doi.org/10.1016/j.ibusrev.2016.11.003

Accepted version made available under the CC-BY-NC-ND 4.0 License from: http://eprints.soas.ac.uk/23283/

Table 2 Tests of Discriminant Validity

\begin{tabular}{|c|c|c|c|c|c|c|c|}
\hline & $\begin{array}{l}\text { Customer } \\
\text { Education }\end{array}$ & $\begin{array}{c}\text { Customer } \\
\text { Participation }\end{array}$ & $\begin{array}{l}\text { Service } \\
\text { Quality }\end{array}$ & Liking & $\begin{array}{c}\text { Affective } \\
\text { Trust }\end{array}$ & $\begin{array}{c}\text { Affective } \\
\text { Commitment }\end{array}$ & Loyalty \\
\hline $\begin{array}{l}\text { Customer } \\
\text { Education }\end{array}$ & $.54-57^{\mathrm{a}}$ & .17 & .42 & .39 & .39 & .36 & .37 \\
\hline $\begin{array}{c}\text { Customer } \\
\text { Participation }\end{array}$ & $.21^{\mathrm{b}}$ & .51 & .10 & .14 & .16 & .20 & .20 \\
\hline Service Quality & .23 & .10 & $.63 \quad .63$ & .52 & .43 & .36 & .42 \\
\hline Liking & .26 & .11 & .62 & & .53 & .37 & .40 \\
\hline Affective Trust & .37 & .18 & .57 & .45 & & .67 & .47 \\
\hline $\begin{array}{c}\text { Affective } \\
\text { Commitment }\end{array}$ & .17 & .03 & .47 & .29 & .57 & .80 & .54 \\
\hline Loyalty & .17 & .03 & .41 & .45 & .47 & .68 & \\
\hline
\end{tabular}

${ }^{\mathrm{a}}$ Values above the line along the diagonal are AVE values for the Greek sample while those below the line are the AVE values for the Chinese sample.

${ }^{\mathrm{b}}$ Values in cells represent the shared variance between a pair of constructs.

Table 3 Construct Means, Std. Deviations, Correlations, and VIFs

\begin{tabular}{|c|c|c|c|c|c|c|c|c|c|c|c|c|c|}
\hline Construct & Mean $_{\text {China }}$ & $\begin{array}{l}\text { Std. } \\
\operatorname{Dev}_{\text {China }}\end{array}$ & Mean $_{\text {Greece }}$ & \begin{tabular}{|l} 
Std. \\
Dev.Greece
\end{tabular} & $\begin{array}{l}\text { Customer } \\
\text { Educatio } \\
n\end{array}$ & $\begin{array}{l}\text { Customer } \\
\text { Participatio } \\
\text { n }\end{array}$ & \begin{tabular}{|l|} 
Servic \\
e \\
Qualit \\
y
\end{tabular} & Liking & $\begin{array}{l}\text { Affective } \\
\text { Trust }\end{array}$ & $\begin{array}{l}\text { Affective } \\
\text { Commitment }\end{array}$ & Loyalty & VIF $_{\text {China }}$ & VIF $_{\text {Greece }}$ \\
\hline $\begin{array}{l}\text { Customer } \\
\text { Education }\end{array}$ & 3.80 & 1.42 & 4.68 & 1.37 & 1.00 & $.344^{\mathrm{a}}$ & .571 & .564 & .554 & .507 & .556 & 1.75 & 2.74 \\
\hline $\begin{array}{l}\text { Customer } \\
\text { Participation }\end{array}$ & 4.05 & 1.35 & 3.77 & 1.57 & .368 & 1.00 & .243 & .338 & .365 & .407 & .419 & 1.39 & 3.77 \\
\hline $\begin{array}{l}\text { Service } \\
\text { Quality } \\
\end{array}$ & 4.71 & 1.33 & 5.19 & 1.16 & .378 & .241 & 1.00 & .662 & .580 & .489 & .594 & 4.08 & 4.10 \\
\hline Liking & 4.74 & 1.31 & 4.93 & 1.30 & .408 & .265 & .674 & 1.00 & .670 & .536 & .604 & 3.69 & 2.87 \\
\hline $\begin{array}{l}\text { Affective } \\
\text { Trust }\end{array}$ & 4.11 & 1.28 & 4.15 & 1.54 & .493 & .337 & .621 & .555 & 1.00 & .746 & .652 & 3.98 & 2.70 \\
\hline $\begin{array}{l}\text { Affective } \\
\text { Commitment }\end{array}$ & 4.23 & 1.43 & 3.55 & 1.86 & .321 & $.136^{*}$ & .543 & .424 & .621 & 1.00 & .687 & 4.76 & 1.35 \\
\hline Loyalty & 4.19 & 1.40 & 4.56 & 1.66 & .361 & $.145^{*}$ & .538 & .552 & .584 & .671 & 1.00 & 4.08 & 2.15 \\
\hline
\end{tabular}

${ }^{\mathrm{a}}$ Values above the diagonal are for the Greek sample; values below the diagonal are for the Chinese sample. All correlations significant at $\mathrm{p}<.01$ unless denoted by ““””.

Since the purpose of the study was to investigate potential differences across the samples, rather than to combine the data, there was no need to conduct a comprehensive analysis of measurement invariance. However, we did assess both configural and metric invariance in order 
to be assured the items were loading similarly across the sample. Configural invariance refers to the extent to which the basic model structure is the same across the groups. Evidence for configural invariance is given, in part, by the fact that we found very similar results for our CFAs for both groups as noted above. In addition, one can more "formally" test for configural invariance by running a model in which both groups are represented. Doing so resulted in a very good fit to the data $\left(\chi^{2}=600.030_{(336)}, \mathrm{p}=.000, \mathrm{CFI}=.96, \mathrm{IFI}=.96\right.$, and SRMR=.03). The next step is to assess metric invariance, which tests to determine if factor loadings are equivalent across the two groups. Since this model is "nested" within the configural model, the test of metric invariance is conducted by constraining the factor loadings to be equivalent across the two samples. The $\chi^{2}$ value from this model is tested relative to that from the configural model to determine if the models are equivalent. If so, one can argue for metric invariance. In our case, the test of metric invariance resulted in a significant degradation in model fit $\left(\chi^{2}\right.$ configural $-\chi^{2}$ metric $=57.58(24), p=.00)$. Although the $\chi^{2}$ difference was significant, the other fit estimates were unchanged with the exception of SRMR which increased to .05. As suggested by Steenkamp and Baumgartner (1998), modification indices and expected parameter changes were analysed to identify items that were contributing to the lack of metric invariance. Two items from the Greek sample, one for Consumer Education ("The bank explains financial concepts and recommendations in a meaningful way") and one for Affective Trust ("I can talk freely with my financial advisor about my problems at work and know that he or she will want to listen”) seemed to be problematic and were allowed to be freely estimated across both samples. This led to a much better model fit and one that is not significantly different from the configural model $(\chi$ ${ }^{2}$ configural $-\chi^{2}$ metric $=22.48(22), \mathrm{p}=.43$ ). Since only two of thirty-six invariance constraints needed 
to be relaxed, we feel confident that the factor loadings are invariant across the three samples and can be used to test the structural model.1.7 Results

The hypotheses represented in Figure 1 were tested using LISREL 8.51 (Jöreskog \& Sörbom, 2001). First, the research model was estimated for the Chinese and Greek samples separately in order to determine test the proposed structural relationships between the constructs. These results are presented in Table 4. Both models resulted in significant $\chi^{2}$ values $\left(367.44_{(179)}, \mathrm{p}<.05\right.$ for the Chinese sample and 502.22(179), $\mathrm{p}<.05$ for the Greek sample). However, other fit statistics indicated what could be considered adequate fit. For the Chinese sample both the CFI and IFI values were .94 while the SRMR was .05. For the Greek sample, CFI and IFI were again .94 with the SRMR being .08. As can be seen in Table 4 all paths are significant and in the direction hypothesized with the exception of the path between customer participation and liking for the Chinese sample.

Table 4 Results of Tests of Structural Relationships

\begin{tabular}{|l|l|l|l|l|l|}
\hline & & \multicolumn{2}{l|}{ Chinese Sample } & \multicolumn{2}{l|}{ Greek Sample } \\
\hline Path & Hypothesis & $\begin{array}{l}\text { Parameter } \\
\text { Estimate }\end{array}$ & t-value & $\begin{array}{l}\text { Parameter } \\
\text { Estimate }\end{array}$ & t-value \\
\hline Consumer Participation $\rightarrow$ Liking & H1 & .21 & 3.17 & .26 & 3.67 \\
\hline Consumer Education $\rightarrow$ Liking & H2 & .04 & .75 & .14 & 2.62 \\
\hline Service Quality $\rightarrow$ Liking & H3 & .77 & 9.77 & .54 & 7.81 \\
\hline Liking $\rightarrow$ Affective Trust & H4 & .83 & 9.73 & .79 & 13.98 \\
\hline Liking $\rightarrow$ Affective Commitment & H5 & .73 & 8.20 & .70 & 10.97 \\
\hline Affective Trust $\rightarrow$ Loyalty & H6 & .22 & 2.82 & .30 & 5.14 \\
\hline Affective Commitment $\rightarrow$ Loyalty & H7 & .70 & 7.47 & .54 & 8.68 \\
\hline
\end{tabular}

${ }^{\mathrm{a}}$ Values are completely standardized parameter estimates. 
Although not hypothesized, we chose to conduct post-hoc tests to determine if any of the structural paths in the model differed between the two countries. This analysis was done via multi-group analysis in LISREL. The covariance matrices used in the analysis of the samples individually were included in a single analysis. First, all paths were constrained to be equal across both groups. This resulted in a $\chi^{2}$ value of 1188.12 . Following this each path was sequentially allowed to be freely estimated across both groups and the resulting $\chi^{2}$ value was compared to 1188.12 . If the value for the constrained model is more than 3.84 greater than the value for the model with the freely estimated parameter one can conclude there is a significant difference in the parameter estimates between the two groups. The result of this analysis is presented in Table 5. As can be seen, the paths differ for four paths (customer participation and customer education to liking and liking to affective commitment and affective trust). In all four cases, the parameter estimate for the Greek sample is larger than that for the Chinese sample indicating that the relationship is stronger for Greeks than for Chinese.

Table 5 Results of Moderation Tests

\begin{tabular}{|c|c|c|c|c|}
\hline & & & \multicolumn{2}{|c|}{ Parameter Estimates } \\
\hline Path & $\chi^{2}$ value & $\begin{array}{l}\text { Difference from Fully } \\
\text { Constrained Model }\end{array}$ & $\begin{array}{l}\text { Chinese } \\
\text { Sample }\end{array}$ & $\begin{array}{l}\text { Greek } \\
\text { Sample }\end{array}$ \\
\hline Consumer Participation $\rightarrow$ Liking & 1182.08 & $6.04^{\mathrm{a}}$ & .15 & .31 \\
\hline Consumer Education $\rightarrow$ Liking & 1183.29 & 4.83 & .04 & .19 \\
\hline Service Quality $\rightarrow$ Liking & 1186.46 & 1.66 & & \\
\hline Liking $\rightarrow$ Affective Trust & 1177.24 & 10.88 & .71 & .92 \\
\hline Liking $\rightarrow$ Affective Commitment & 1174.69 & 13.43 & .59 & .86 \\
\hline Affective Trust $\rightarrow$ Loyalty & 1187.86 & .26 & & \\
\hline Affective Commitment $\rightarrow$ Loyalty & 1188.09 & .03 & & \\
\hline
\end{tabular}

${ }^{\mathrm{a}}$ Values greater than 3.84 indicate significant moderation. 


\subsection{Discussion}

The results of the hypotheses tests indicate strong support for the research model regarding both the Chinese and Greek samples, except for the relationship between customer education and liking in the Chinese sample. In addition, the overall strong support for the model not only substantiates the theoretical foundation but also provides evidence that in collectivist cultures, such as China and Greece, liking can play an important role in creating positive outcomes with retail service providers. The fact that the model has a better estimate in the Greek sample is not surprising. The weak estimate for customer education in the Chinese sample can be explained in part by the fact that the banking system in China has in recent years been privatized, though strict government control is still in place. These restrictions may have influenced banks' ability to invest in educating their customers, which would clearly impact the customer relationship liking. This is compared to the Greek banking system that has been liberalized for many decades in Greece.

Unlike studies of liking in the fields of B2B (e.g., Nicholson et al., 2001) and advertising (e.g., Walker \& Dubitsky, 1994) that have drawn heavily on social-psychology, our model conceptualizes the antecedents of customer liking in retail services as being more in line with competence-related constructs rather than pure psychologically based constructs. While the three competency components (customer education, customer participation and service quality) included in our model are based on the concept of co-production of services (Auh et al., 2007), our results point out the fact that liking is not worth a great deal in and of itself (Jayanti \& Whipple, 2008). Rather, liking acts to significantly intervene in the relationship between competence-based service constructs and the affective constructs (commitment and trust) included in our model and, ultimately, loyalty. 
Although knowledgeable customers are generally considered to be able to make a more meaningful contribution to co-production, which increases loyalty (Auh et al., 2007), our results indicate that customer education increases customer liking which, in turn, increases loyalty. One interpretation of this is that the potential for decreases in loyalty and increases in customer switching due to greater customer expertise (Bell \& Eisingerich, 2007) is mitigated by the extent to which liking positively impacts affective commitment and trust. In other words, educating customers about complex services allows customers to make greater contributions to service delivery, strengthens the relationship, and enhances loyalty, which can, in turn, signal a high level of care and empathy felt by the service provider towards the customer. We believe this increases their liking of the relationship.

The positive and significant relationship between customer participation and customer liking confirms our expectation that, in a complex service context, customers are motivated to participate in service production. Thus, a mutual understanding with the service provider must be developed which aids the service provider in delivering a more customized service (Bettencourt, 1997). Participating in service production and provision allows customers to develop a more profound degree of liking which leads to greater levels of affective trust and affective commitment and, ultimately, increased loyalty. Predictably, there is a positive and significant relationship between service quality and customer liking. In fact, the major antecedent of liking in both countries is service quality.

Despite the low estimates on some of the antecedents, the influence of liking on affective trust and commitment in both countries is highly significant. This further emphasizes the important role of customer liking as an intervening factor between the three core competency components and two relationship cornerstones, trust and commitment. Finally, affective trust and 
This is the version of the article accepted for publication in International Business Review published by Elsevier, available at: http://dx.doi.org/10.1016/j.ibusrev.2016.11.003

Accepted version made available under the CC-BY-NC-ND 4.0 License from: http://eprints.soas.ac.uk/23283/

affective commitment are found to influence loyalty. However, affective commitment is by far more influential on loyalty than affective trust. This particular finding supports the suggestion by Fullerton (2003) that "commitment to the service provider would be a very important driver of customer loyalty in services industries” (p. 333).

\subsection{Managerial Implications}

A number of important implications for managers accrue from our study. First, banks that work to establish stronger relationships with their customers, where co-production of value is central to their activities, will need to educate their frontline service personnel (e.g., financial advisors) on the importance of behaving in ways that will develop and maintain their customers liking of them. This may be particularly important for banks that come from individualist cultures (e.g., the US) that are entering China or Greece where financial advisors may not necessarily understand the implicit need for liking in the relationship by customers.

Second, although our findings show customer education to have no significant impact on liking in China, we believe that this may change in the future especially with the rapid Westernization of the banking system in China as well as with the generational changes that are occurring. We, therefore, believe that, as customers in China increasingly become more sophisticated consumers, customer education will be recognized as an important need for their co-production of value. Thus, banks should not ignore or neglect investing in educating Chinese customers about their services.

Third, banks need to understand the best ways to educate their customers regarding the services that many customers may typically find difficult to understand. One way to increase such occurrences might be for service providers to ensure their organizational culture is 
This is the version of the article accepted for publication in International Business Review published by Elsevier, available at: http://dx.doi.org/10.1016/j.ibusrev.2016.11.003

Accepted version made available under the CC-BY-NC-ND 4.0 License from: http://eprints.soas.ac.uk/23283/

supportive of the various ways in which financial advisors can act to improve their customers' knowledge and their ability to make meaningful contributions to service provision. Additionally, educated customers need a greater degree of flexibility and responsiveness from advisors to accommodate their co-production initiatives. As a result, advisors may need further training and development on making such service initiatives mutually beneficial in the relationship, by which liking is enhanced.

Fourth, once liking is established in the relationship, banks need to view it as a tool for the co-management of relationships. In such cases, liking can make up for failures in any of the core competence-related components (customer participation, education, or service quality) and at the same time allows customers to positively engage and helps in the recovery of any failure. In addition, in the event that a service failure occurs, liking helps to protect the levels of trust and commitment in the relationship, and ultimately consumer loyalty. Banks need to give customers more space to participate and to use the level of liking in the service provider-customer relationship to further engage in co-production initiatives and to ensure that the level of service quality expected is met in the service delivery.

\subsection{Limitations and Future Research}

The findings from this study need to be considered in light of key limitations. First, we study the relationship between customers and financial advisors within two collectivist Asian (China) and European (Greece) cultures. Research should first be conducted using a sample from a more individualist culture and then work could expand to look at other cultural dimensions (e.g., uncertainty avoidance, power distance) to determine if the model is generalizable beyond the collectivist/individualist dimension. Our inclusion of Greece as a European country was aimed at 
investigating the extent to which customers from collectivist cultures are always keen to have high relationship liking with their financial providers.

Second, we examined the concept of liking at an 'etic' level of two collectivist cultures (Greece and China). Although the comparison of liking in different cultures has not received much attention by researchers, future studies should aim exploring an 'emic' level liking. Such studies can fill an apparent gap in the literature of international business and significantly improve our understanding of liking in relation to culture.

Third, it is also necessary to include other types of service and/or retail contexts. As the use of banking services represents a somewhat complex service, research should be conducted to determine if our findings hold across other types of services, including those that are less complex. For example, research might be conducted in hospitality-related services (e.g., hotels and restaurants).

Fourth, our conceptual model has solely focused on what we identified from the literature as the core competence-related components in services that drive customer liking. While our conceptual focus can help with the generalizability of the study, especially when the model is tested in collectivist cultures, future studies may consider constructs of a more emotional nature that may drive customer liking in both collectivist and individualist cultures. In addition, the consequences of liking in our model were mainly affective trust and affective commitment. Research should test more cognitive aspects of trust and commitment.

Finally, only one hypothesis, from customer education to liking, was found to be insignificant in the Chinese sample. Given China's emerging economy, and the relatively recent development of the privatized banking system in China in particular, it is possible that Chinese customers and banks may lack sophistication in and awareness of how important customer 
This is the version of the article accepted for publication in International Business Review published by Elsevier, available at: http://dx.doi.org/10.1016/j.ibusrev.2016.11.003

Accepted version made available under the CC-BY-NC-ND 4.0 License from: http://eprints.soas.ac.uk/23283/

education is for complex services. Future research can further examine this finding and perhaps include an Asian collectivist culture that has an advanced banking system, such as Japan.

Despite these limitations, we believe the study brings some new and valuable insights into the area of value co-production and customer relationships in the context of financial services. We believe this is particularly with regard to the important role of liking in driving and managing the customer-service employee relationship and in building loyalty. Understanding factors associated with liking can be seen as an initial step for employees/managers towards accepting the view of co-management of relationships and as a source of competitiveness for their bank.

\subsection{References}

Aaker, D.A. (1996), Building Strong Brands, The Free Press, New York, NY.

Abosag, I. \& Naudé, P. (2014). Development of special forms of B2B relationships: Examining the role of interpersonal liking in developing Guanxi and Et-Moone relationships. Industrial Marketing Management, 43(6), 887-896.

Abosag, I., \& Lee, J. (2013). The formation of trust and commitment in business relationships in the Middle East: Understanding Et-Moone relationships. International Business Review, 21, (6), 602-614.

Altman, I. \& Taylor, D. A. (1973). Social Penetration: The Development of Interpersonal Relationships. Holt, Rinehart \& Winston: New York, NY.

Amine, A. (1998). Consumers' true brand loyalty: the central role of commitment. Journal of Strategic Marketing, 6(4), 305-319. 
This is the version of the article accepted for publication in International Business Review published by Elsevier, available at: http://dx.doi.org/10.1016/j.ibusrev.2016.11.003

Accepted version made available under the CC-BY-NC-ND 4.0 License from: http://eprints.soas.ac.uk/23283/

Antón, C., Camarero, C. \& Carrero, M. (2007). Analysing firms’ failures as determinants of consumer switching intentions: The effect of moderating factors. European Journal of Marketing,41 (1/2), 135-158.

Auh, S., Bell, S. J., McLeod, C. S. \& Shih, E. (2007). Co-production and customer loyalty in financial services. Journal of Retailing, 83 (3), 359-370.

Bailey, N. \& Areni, C. S. (2006). When a few minutes sound like a lifetime: Does atmospheric music expand or contract perceived time? Journal of Retailing, 82 (3), 189-202.

Baker, T. L., Meyer, T. \& Chebat, J. (2013). Cultural impacts on felt and expressed emotions and third party complaint relationships. Journal of Business Research, 66 (7), 816-822.

Bateson, J. E. (1985). Self-service consumer: An exploratory study. Journal of Retailing, 61 (3), 49-76.

Bell, S. J. \& Eisingerich, A. B. (2007). The paradox of customer education: Customer expertise and loyalty in the financial services industry. European Journal of Marketing, 41 (5/6), 466486.

Bendapudi, N. \& Berry, L. L. (1997). Customers' motivations for maintaining relationships with service providers. Journal of Retailing, 73 (1), 15-37.

Bendapudi, N. \& Leone, R.P. (2003). Psychological implications of customer participation in coproduction. Journal of Marketing, 67 (1), 14-28.

Berry, L. L. (1983), “Relationship marketing”, In L. L. Berry, G. L. Shostack, \& G. Upah. (Eds.), Emerging Perspectives on Services Marketing, American Marketing Association, (25-28), Chicago: IL.

Bettencourt, L. A. (1997). Customer voluntary performance: customers as partners in service delivery. Journal of Retailing, 73 (3), 383-406. 
This is the version of the article accepted for publication in International Business Review published by Elsevier, available at: http://dx.doi.org/10.1016/j.ibusrev.2016.11.003

Accepted version made available under the CC-BY-NC-ND 4.0 License from: http://eprints.soas.ac.uk/23283/

Bettis-Outland, H., Guo, L. \& Ng, I. C. (2012). The antecedents of salespeople's relational behaviors. Journal of Business \& Industrial Marketing, 27 (5), 412-419.

Bitner, M., Faranda, W. T., Hubbert, A. R., \& Zeithaml, V. A. (1997). Customer contributions and roles in service delivery. International Journal of Service Industry Management, 8 (3), 193-205.

Bitner, M. J., Booms, B. H. \& Tetreault, M. S. (1990). The service encounter: diagnosing favorable and unfavorable incidents. Journal of Marketing, 54 (1), 71-84.

Bolton, R.N. \& Drew, J.H. (1991). A multistage model of customers' assessments of service quality and value. Journal of Consumer Research, 17 (4), 375-384.

Bove, L. L. \& Johnson, L. W. (2001). Customer relationships with service personnel: do we measure closeness, quality or strength? Journal of Business Research, 54 (3), 189-197.

Bowen, D. E. \& Schneider, B. (1988). Services marketing and management-implications for organizational-behavior. In B.M. Staw and L. L. Cummings (Eds.), Research in Organizational Behavior, (43-80), Vol. 10, JAI Press, Inc.: Greenwich, CT.

Brady, M.K., Cronin, J.J. \& Brand, R.R. (2002), "Performance-only measurement of service quality: a replication and extension", Journal of Business Research, Vol. 55, No. 1, 17-31.

Brislin, R. (1986). The wording and translation of research instruments. In Lonner, W. and Berry, J., Field Methods in Cross-Cultural Research, (137-164), Sage Publication: London.

Burton, D. (2002). Consumer education and service quality: conceptual issues and practical implications. Journal of Services Marketing, 16 (2), 125-142. 
Burton, S., Howlett, E. \& Tangari, A. H. (2009). Food for thought: How will the nutrition labeling of quick service restaurant menu items influence consumers’ product evaluations, purchase intentions, and choices? Journal of Retailing, 85 (3), 258-273.

Byrne, D. E. (1971). The Attraction Paradigm, Academic Press: New York, NY.

Caballero, M. \& Resnik, A. J. (1986). The attraction paradigm in dyadic exchange. Psychology \& Marketing, 3 (1), 17-34.

Carnevale, P. J., Pruitt, D.G. \& Carrington, P. I. (1982). Effects of future dependence, liking, and repeated requests for help on helping behaviour. Social Psychology Quarterly, 45 (1), 9-14.

Cater, B., \& Zabkar, V. (2009). Antecedents and consequences of commitment in marketing research services: The client's perspective. Industrial Marketing Management, 38(7), 785797.

Cialdani, R. (2004). Influence: Science and Practice, $4^{\text {th }}$ ed., Allyn and Bacon: Needham Heights, MA.

Clarke, K. \& Belk, R. W. (1979). The effects of product involvement and task definition on anticipated consumer effort. Advances in Consumer Research, 6 (1), 313-318.

Cox, D. \& Cox, A. D. (2002). Beyond first impressions: The effects of repeated exposure on consumer liking of visually complex and simple product designs. Journal of the Academy of Marketing Science, 30 (2), 119-130.

Dabholkar, P. A. (1990). How to improve perceived service quality by increasing customer participation. Proceedings of the 1990 Academy of Marketing Science (AMS) Annual Conference, Springer, 483-487. 
Dabholkar, P. A., Shepherd, C. D. \& Thorpe, D. I. (2000). A comprehensive framework for service quality: an investigation of critical conceptual and measurement issues through a longitudinal study. Journal of Retailing, 76 (2), 139-173.

Davis, M. R. (1985). Perceptual and affective reverberation components. In A. P. Goldstein \& G. Y. Michaels (Eds.), Empathy: Development, Theory, and Consequences, (62-108), Erlbaum: Hillsdale, NJ,.

Dean, A. M. (2007). The impact of the customer orientation of call center employees on customers' affective commitment and loyalty. Journal of Service Research, 10 (2), 161-173.

Dellande, S., Gilly, M. C. \& Graham, J. L. (2004). Gaining compliance and losing weight: The role of the service provider in health care services. Journal of Marketing, 68 (3), 78-91.

Dobscha, S. \& Foxman, E. (2012). Mythic agency and retail conquest. Journal of Retailing, 88 (2), 291-307.

Doney, P. M. \& Cannon, J. P. (1997). An examination of the nature of trust in buyer-seller relationships. Journal of Marketing, 51 (2), 35-51.

Dowell, D., Morrison, M. \& Heffernan, T. (2015).The changing importance of affective trust and cognitive trust across the relationship lifecycle: A study of business-to-business relationships. Industrial Marketing Management, 44, 119-130.

Dwyer, C. (2007). Digital relationships in the "myspace" generation: Results from a qualitative study. In 40th Annual Hawaii International Conference on System Sciences, 2007, HICSS 2007, IEEE, 19.

Dwyer, F. R., Schurr, P. H. \& Oh, S. (1987). Developing buyer-seller relationships. Journal of Marketing, 51 (2), 11-27. 
This is the version of the article accepted for publication in International Business Review published by Elsevier, available at: http://dx.doi.org/10.1016/j.ibusrev.2016.11.003

Accepted version made available under the CC-BY-NC-ND 4.0 License from: http://eprints.soas.ac.uk/23283/

Edvardsson, B., Gustafsson, A., Kristensson, P. \& Witell, L. (2010). Service innovation and Customer co-development. In Maglio, P. P., Kieliszewski, C. A., \& Spohrer, J. C. (Eds.), Handbook of Service Science, (561-577), Springer: New York.

Eiglier, P., \& Langeard, E. (1977). A new approach to service marketing. In Marketing Consumer Services: New Insights, Report, (77-115), Marketing Science Institute: Boston, MA.

Eisingerich, A. B. \& Bell, S. J. (2006). Relationship marketing in the financial services industry: The importance of customer education, participation and problem management for customer loyalty. Journal of Financial Services Marketing, 10 (4), 86-97.

Ennew, C. T. \& Binks, M. R. (1999). Impact of participative service relationships on quality, satisfaction and retention: an exploratory study. Journal of Business Research, 46 (2), 121132.

Escalas, J. and Bettman, J. (2005). Self-construal, reference groups and brand meaning. Journal of Consumer Research, 32(3), 378-389.

Escalas, J. and Bettman, J. (2009). Self-brand connections: the role of reference groups and celebrity endorsers in the creation of brand meaning. In Maclnnis, D., Park, C. and Priester, J. (eds), Handbook of Brand Relationships, Armonk, NY: M. E. Sharpe, 107-123.

Evanschitzky, H., Iyer, G. R., Plassmann, H., Niessing, J. \& Meffert, H. (2006). The relative strength of affective commitment in securing loyalty in service relationships. Journal of Business Research, 59 (12), 1207-1213.

Fang, E. (2008). Customer participation and the trade-off between new product innovativeness and speed to market. Journal of Marketing, 72 (4), 90-104. 
This is the version of the article accepted for publication in International Business Review published by Elsevier, available at: http://dx.doi.org/10.1016/j.ibusrev.2016.11.003

Accepted version made available under the CC-BY-NC-ND 4.0 License from: http://eprints.soas.ac.uk/23283/

Folse, J. A., Niedrich, R. W. \& Grau, S. L. (2010). Cause-relating marketing: The effects of purchase quantity and firm donation amount on consumer inferences and participation intentions. Journal of Retailing, 86 (4), 295-309.

Fornell, C. \& Larcker, D. F. (1981). Evaluating structural equation models with unobservable variables and measurement error. Journal of Marketing Research, 18 (1), 39-50.

Fournier, S. (1998). Consumers and their brands: developing relationship theory in consumer research. Journal of Consumer Research, 24(3), 343 - 373.

Fullerton, G. (2003). When does commitment lead to loyalty? Journal of Service Research, 5 (4), 333-344.

Furrer, O., Liu, B. S. \& Sudharshan, D. (2000). The relationships between culture and service quality perceptions basis for cross-cultural market segmentation and resource allocation. Journal of Service Research, 2 (4), 355-371.

Garbarino, E. \& Johnson, M. S. (1999). The different roles of satisfaction, trust, and commitment in customer relationships. Journal of Marketing, 63 (2), 70-87.

Geyskens, I., Steenkamp, J. E., Scheer, L. K. \& Kumar, N. (1996). The effects of trust and interdependence on relationship commitment: A trans-Atlantic study. International Journal of Research in Marketing, 13 (4), 303-317.

Gremler, D. D. \& Gwinner, K. P. (2008). Rapport-building behaviors used by retail employees. Journal of Retailing, 84 (3), 308-324.

Gundlach, G. T., Achrol, R. S. \& Mentzer, J. T. (1995). The structure of commitment in exchange. Journal of Marketing, 59 (1), 78-92.

Hall, J., Horgan, T., Stein, T. \& Roter, D. (2002). Liking in the physician-patient relationship. Patient Education and Counselling, 48, 69-77. 
This is the version of the article accepted for publication in International Business Review published by Elsevier, available at: http://dx.doi.org/10.1016/j.ibusrev.2016.11.003

Accepted version made available under the CC-BY-NC-ND 4.0 License from: http://eprints.soas.ac.uk/23283/

Harris, L. C. \& Goode, M. M. (2004). The four levels of loyalty and the pivotal role of trust: a study of online service dynamics. Journal of Retailing, 80 (2), 139-158.

Hawke, A. \& Heffernan, T. (2006). Interpersonal liking in lender-customer relationships in the Australian banking sector. International Journal of Bank Marketing, 24 (3), 140-157.

Hayes, B. J., Alford, B. L., Silver, L., and York, R. P. (2006). Looks matter in developing consumer-brand relationships. Journal of Product \& Brand Management, 15(5),306-315.

Hendrick, C., \& Hendrick, S. (1983). Liking, loving and relating, Brooks/Cole: Pacific Grove, CA.

Hofstede, G., (2001). Culture’s Consequences: Comparing Values, Behaviors, Institutions, and Organizations Across Nations. $2^{\text {nd }}$ Edition. Sage: Thousand Oaks, CA.

Hofstede, G., Hofstede, G.J. \& Minkov, M., (1991). Cultures and organizations: Software of the mind (Vol. 2). London: McGraw-Hill.

Hu, L. \& Bentler, P. M. (1999). Cutoff criteria for fit indexes in covariance structure analysis: Conventional criteria versus new alternatives. Structural Equation Modeling: A Multidisciplinary Journal, 6 (1), 1-55.

Hurley, R.F. \& Estelami, H. (1998). Alternative indexes for monitoring customer perceptions of service quality: A comparative evaluation in a retail context. Journal of the Academy of Marketing Science, 26 (3), 209-221.

Jaros, S. J., Jermier, J. M., Koehler, J. W. \& Sincich, T. (1993). Effects of continuance, affective, and moral commitment on the withdrawal process: An evaluation of eight structural equation models. Academy of Management Journal, 36 (5), 951-995. 
Jayakody, J.A. \& Sanjeewani, W.M. (2006). The impact of salesperson transformational leadership behavior on customer relationship marketing behavior: A study of the Sri Lankan corporate banking sector. International Journal of Bank Marketing, 24(7), 461-474.

Jayanti, R. K. \& Whipple, T. W. (2008). Like me... like me not: the role of physician likability on service evaluations. Journal of Marketing Theory and Practice, 16 (1), 79-86.

Johnson, D. \& Grayson, K. (2005). Cognitive and affective trust in service relationships. Journal of Business Research, 58 (4), 500-507.

Jöreskog, K. G., \& Sörbom, D. (2001). LISREL software version 8.51. Scientific Software International: Chicago, IL.

Kandampully, J. \& Hu, H. (2007). Do hoteliers need to manage image to retain loyal customers? International Journal of Contemporary Hospitality Management, 19 (6), 435-443.

Karjaluoto, H., Laukkanen, T. \& Kiviniemi, V. (2010). The role of information in mobile banking resistance. International Journal of Bank Marketing, 28 (5), 372-388.

Keaveney, S. M. (1995). Customer switching behavior in service industries: An exploratory study. Journal of Marketing, 59 (2), 71-82.

Keller, K. L. (1993). Conceptualizing, measuring, and managing customer-based brand equity. Journal of Marketing, 57 (1), 1-22.

Kelley, S. W. \& Hoffman, K. D. (1997). An investigation of positive affect, prosocial behaviors and service quality. Journal of Retailing, 73 (3), 407-427.

Kelley, S. W., Donnelly, J. H. \& Skinner, S. J. (1990). Customer participation in service production and delivery. Journal of Retailing, 73 (3), 407-427. 
This is the version of the article accepted for publication in International Business Review published by Elsevier, available at: http://dx.doi.org/10.1016/j.ibusrev.2016.11.003

Accepted version made available under the CC-BY-NC-ND 4.0 License from: http://eprints.soas.ac.uk/23283/

Khare, A., Labrecque, L. I. \& Asare, A. K. (2011). The assimilative and contrastive effects of word-of-mouth volume: An experimental examination of online consumer ratings. Journal of Retailing, 87 (1), 111-126.

Kim, S. K., Hibbard, J. D. \& Swain, S. D. (2011). Commitment in marketing channels: Mitigator or aggravator of the effects of destructive acts? Journal of Retailing, 87 (4), 521-539.

Kristensson, P., Gustafsson, A. \& Archer, T. (2004). Harnessing the creative potential among users. Journal of Product Innovation Management, 21 (1), 4-14.

Lai, F., Griffin, M. \& Babin, B. J. (2009). How quality, value, image, and satisfaction create loyalty at a Chinese telecom. Journal of Business Research, 62 (10), 980-986.

Lee, Y., Kim, S. \& Yoo, J. (2009). Impact of technology-based self-service on employees, customers, and Sales in the Korean services market. Journal of Business Market Management, 3 (3), 171-183.

Lengnick-Hall, C. A. (1996). Customer contributions to quality: A different view of the customer-oriented firm. Academy of Management Review, 21 (3), 791-824.

Levitt, T. (1980). Marketing success through differentiation-of anything. (83-91), Graduate School of Business Administration, Harvard University: Boston.

Lewis, J. D. \& Weigert, A. (1985). Trust as a social reality. Social Forces, 63 (4), 967-985.

Liden, R. C., Wayne, S. J. \& Stilwell, D. (1993). A longitudinal study on the early development of leader-member exchanges. Journal of Applied Psychology, 78 (4), 662-674.

Locke, E. A. (1964). The relationship of task success to task liking and satisfaction. Journal of Applied Psychology, 49 (5), 379-385.

Lovelock, C. H. \& Young, R. F. (1979). Look to consumers to increase productivity. Harvard Business Review, 57 (3), 168-178. 
This is the version of the article accepted for publication in International Business Review published by Elsevier, available at: http://dx.doi.org/10.1016/j.ibusrev.2016.11.003

Accepted version made available under the CC-BY-NC-ND 4.0 License from: http://eprints.soas.ac.uk/23283/

Mangold, W.G. \& Faulds, D.J., (2009). Social media: The new hybrid element of the promotion mix. Business Horizons, 52(4), 357-365.

Mattila, A. S. (1999). The role of culture in the service evaluation process", Journal of Service Research, 1 (3), 250-261.

McNeal, J.U., (1978). Consumer education as a competitive strategy. Business Horizons, 21(1), $50-56$.

Meyer, J. P. \& Allen, N. J. (1991). A three-component conceptualization of organizational commitment. Human Resource Management Review, 1 (1), 61-89.

Mohr, L. A. \& Bitner, M. J. (1991). Mutual understanding between customers and employees in service encounters. Advances in Consumer Research, 18 (1), 611-617.

Moorman, C., Zaltman, G. \& Deshpande, R. (1992). Relationships between providers and users of market research: The dynamics of trust. Journal of Marketing Research, 29 (3), 314-328.

Moutinho, L. \& Smith, A. (2000). Modelling bank customer satisfaction through mediation of attitudes towards human and automated banking. International Journal of Bank Marketing, 18 (3), 124-134.

Mukherjee, A. \& Balmer, J.M., (2007). Preface: New frontiers and perspectives in corporate brand management: in search of a theory. International Studies of Management \& Organization, 37(4), 3-19.

Mukherjee, A. \& He, H., (2008). Company identity and marketing: an integrative framework. Journal of Marketing Theory and Practice, 16(2), 111-125.

Nayyar, P.R. (1990). Information asymmetries: A source of competitive advantage for diversified service firms. Strategic Management Journal, 11 (7), 513-519. 
Nguyen, B., Melewar, T. C., \& Chen, J. (2013). The brand likeability effect: Can firms make themselves more likeable? Journal of General Management, 38 (3), 25-50.

Nicholson, C. Y., Compeau, L.D. \& Sethi, R. (2001). The role of interpersonal liking in building trust in long-term channel relationships. Journal of the Academy of Marketing Science, 29 (1), 3-15.

Norton, M. I., Frost, J. H. \& Ariely, D. (2007). Less is more: the lure of ambiguity, or why familiarity breeds contempt. Journal of Personality and Social Psychology, 92 (1), 97-105.

O'Malley, L. \& Tynan, C. (1997). A reappraisal of the relationship marketing constructs of commitment and trust. New and evolving paradigms: The Emerging Future of Marketing Conference, 486-503.

Parasuraman, A., Zeithaml, V. A. \& Berry, L. L. (1985). A conceptual model of service quality and its implications for future research. Journal of Marketing, 49 (4), 41-50.

Parasuraman, A., Zeithaml, V. A. \& Berry, L. L. (1994). Reassessment of expectations as a comparison standard in measuring service quality: implications for further research. Journal of Marketing, 70 (3), 111-124.

Pimentel, R. W. \& Reynolds, K. E. (2004). A model for consumer devotion: Affective commitment with proactive sustaining behaviors. Academy of Marketing Science Review, 5, (1), 1-45.

Price, L. L., Arnould, E. J. \& Deibler, S. L. (1995). Consumers' emotional responses to service encounters: the influence of the service provider. International Journal of Service Industry Management, 6 (3), 34-63. 
Reimann, M. and Aron, A. (2009). Self-expansion motivation and inclusion of brands in the self: towards a theory of brand relationships. In Maclnnis, D., Park, C. and Priester, J. (eds), Handbook of Brand Relationships, Armonk, NY: M. E. Sharpe, 65-81.

Rempel, J. K., Holmes, J. G. \& Zanna, M. P. (1985). Trust in close relationships. Journal of Personality and Social Psychology, 49 (1), 95.

Rodie, A. R. \& Kleine, S. S. (2000). Customer participation in services production and delivery. In Swartz, T.A. and Iacobucci D. (Eds.), Handbook of Services Marketing and Management, (111-126), Sage: Thousand Oaks, CA.

Rodríguez, C. M., \& Wilson, D. T. (2002). Relationship bonding and trust as a foundation for commitment in US-Mexican strategic alliances: A structural equation modeling approach. Journal of International Marketing, 10 (4), 53-76.

Rotter, J.B. (1980). Interpersonal trust, trustworthiness, and gullibility. American Psychologist, $35(1), 1-7$.

Sanders, T. (2006). The Likeability Factor: How to Boost Your L-Factor and Achieve Your Life's Dreams. Three Rivers Press: New York, NY.

Schaubroeck, J., Lam, S. S., \& Peng, A. C. (2011). Cognition-based and affect-based trust as mediators of leader behavior influences on team performance. Journal of Applied Psychology, 96 (4), 863-871.

Schneider, B. \& Bowen, D. E. (1985). Employee and customer perceptions of service in banks: Replication and extension. Journal of Applied Psychology, 70 (3), 423.

Schurr, P. H. \& Ozanne, J. L. (1985). Influences on exchange processes: Buyers' preconceptions of a seller's trustworthiness and bargaining toughness. Journal of Consumer Research, 11 (4), 939-953. 
This is the version of the article accepted for publication in International Business Review published by Elsevier, available at: http://dx.doi.org/10.1016/j.ibusrev.2016.11.003

Accepted version made available under the CC-BY-NC-ND 4.0 License from: http://eprints.soas.ac.uk/23283/

Segars, A. H. (1997). Assessing the unidimensionality of measurement: a paradigm and illustration within the context of information systems research. Omega, 25 (1), 107-121.

Sharma, N. \& Patterson, P.G. (1999). The impact of communication effectiveness and service quality on relationship commitment in consumer, professional services. Journal of Services Marketing, 13 (2), 151-170.

Sivakumar, K., Li, M. \& Dong, B. (2014). Service quality: the impact of frequency, timing, proximity, and sequence of failures and delights. Journal of Marketing, 78 (1), 41-58.

Smith, N. C., \& Cooper-Martin, E. (1997). Ethics and target marketing: The role of product harm and consumer vulnerability. Journal of Marketing, 31 (3), 1-20.

Spence, C., Puccinelli, N. M., Grewal, D. \& Roggeveen, A. L. (2014). Store atmospherics: A multisensory perspective. Psychology \& Marketing, 31(7), 472-488.

Steenkamp, J.B.E. \& Baumgartner, H., (1998). Assessing measurement invariance in crossnational consumer research. Journal of Consumer Research, 25(1), 78-107.

Sternberg, R.J. (1987). Liking versus loving: A comparative evaluation of theories.

Psychological Bulletin, 102 (3), 331-345.

Stone, M. H. (2007) Personality-Disordered Patients: Treatable and Untreatable. American Psychiatric Publishing: Arlington, VA.

Suwelack, T., Hogreve, J. \& Hoyer, W. D. (2011). Understanding money-back guarantees: Cognitive, affective, and behavioral outcomes. Journal of Retailing, 87 (4), 462-478.

Swan, J.E., Trawick, I.F. \& Silva, D.W. (1985). How industrial salespeople gain customer trust. Industrial Marketing Management, 14 (3), 203-211. 
This is the version of the article accepted for publication in International Business Review published by Elsevier, available at: http://dx.doi.org/10.1016/j.ibusrev.2016.11.003

Accepted version made available under the CC-BY-NC-ND 4.0 License from: http://eprints.soas.ac.uk/23283/

Taylor, S. A. \& Baker, T. L. (1994). An assessment of the relationship between service quality and customer satisfaction in the formation of consumers' purchase intentions. Journal of Retailing, 70 (2), 163-178.

Vargo, S.L. \& Lusch, R.F. (2004). Evolving to a new dominant logic for marketing. Journal of Marketing, 68 (1), 1-17.

Verhoef, P. C., Lemon, K. N., Parasuraman, A., Roggeveen, A., Tsiros, M. \& Schlesinger, L. A. (2009). Customer experience creation: Determinants, dynamics and management strategies. Journal of Retailing, 85 (1), 31-41.

Walker, D. \& Dubitsky, T. M. (1994), Why liking matters. Journal of Advertising Research, 43 (3), 9-18.

Wang, E. (2014). The effects of relationship bonds on emotional exhaustion and turnover intentions in frontline employees. Journal of Services Marketing, 28 (4), 319-330.

Wetzels, M., De Ruyter, K. \& Van Birgelen, M. (1998). Marketing service relationships: the role of commitment. Journal of Business \& Industrial Marketing, 13 (4/5), 406-423.

Williams, J., Han, S. and Qualls, W. (1998). A conceptual model and study of cross-cultural business relationships. Journal of Business Research, 42 (2), 135-143.

Winsted, K. F. (1997). The service experience in two cultures: A behavioral perspective. Journal of Retailing, 73 (3), 337-360.

Wong, A. (2004). The role of emotional satisfaction in service encounters. Managing Service Quality: An International Journal, 14 (5), 365-376.

Xue, M. \& Harker, P. T. (2002). Customer efficiency concept and its impact on e-business Management. Journal of Service Research, 4 (4), 253-267. 
This is the version of the article accepted for publication in International Business Review published by Elsevier, available at: http://dx.doi.org/10.1016/j.ibusrev.2016.11.003

Accepted version made available under the CC-BY-NC-ND 4.0 License from: http://eprints.soas.ac.uk/23283/

Ye, G. \& Van Raaij, W. F. (2004). Brand equity: extending brand awareness and liking with Signal Detection Theory. Journal of Marketing Communications, 10 (2), 95-114.

Yim, C. K. B., Chan, K. W. \& Hung, K. (2007). Multiple reference effects in service evaluations: Roles of alternative attractiveness and self-image congruity. Journal of Retailing, 83 (1), 147-157.

Zaccaro, S. J. \& McCoy, M. C. (1988). The Effects of task and interpersonal cohesiveness on performance of a disjunctive group task1. Journal of Applied Social Psychology, 18 (10), 837-851.

Zajonc, R. B. (1980). Feeling and thinking: Preferences need no inferences. American psychologist, 35 (2), 151.

Zayer, L., and Neier, S. (2011). An exploration of men’s brand relationships. Qualitative Market Research: An International Journal, 14(1), 83-104.

Zeithaml, V. A. (1988). Consumer perceptions of price, quality, and value: a means-end model and synthesis of evidence. Journal of Marketing, 52 (3), 2-22.

Zeithaml, V. A., Berry, L. L. \& Parasuraman, A. (1996). The behavioral consequences of service quality. Journal of Marketing, 60 (2), 31-46. 